\title{
A Facile and Efficient Synthesis of (15R)-Latanoprost from Chiral Precursor Corey Lactone Diol
}

\author{
K VIJENDHAR $^{\mathrm{a}, \mathrm{b}}$, B SRINIVAS $^{\mathrm{b}}$ and SATHYANARAYANA BOODIDA ${ }^{\mathrm{a}, *}$ \\ ${ }^{a}$ Department of Chemistry, JNTUH College of Engineering Jagtial, Karimnagar 505 501, India \\ ${ }^{b}$ R\&D Division, Aspen Bio Pharma Labs Pvt. Ltd, Genome Vally, Turkapally, Hyderabad 500 078, India \\ e-mail: bs14@jntuh.ac.in
}

MS received 29 June 2015; revised 1 September 2015; accepted 3 September 2015

\begin{abstract}
An efficient asymmetric synthetic route for the synthesis of anti-glaucoma agent, (15R)-latanoprost using Corey lactone diol as chiral substrate under Swern oxidation, allylic reduction and Wittig reaction conditions has been developed. In this method, reduction of keto and alkene functional groups has been achieved in a single step using low cost catalyst $\mathrm{NiCl}_{2} / \mathrm{NaBH}_{4}$ in methanol. This new synthetic protocol is a good alternative for the synthesis of latanoprost with high stereo selectivity and improved yield.
\end{abstract}

Keywords. Latanoprost; Corey lactone diol; Swern oxidation; Allylic reduction; Wittig reaction.

\section{Introduction}

Prostaglandins are a class of naturally occurring lipid compounds. The active prostaglandins produced in vivo are: prostaglandin (PGE2), prostacyclin (PGI2), prostaglandin D2 (PD2) and prostaglandin $\mathrm{F}_{2 \alpha}\left(\mathrm{PGF}_{2 \alpha}\right)$. Prostaglandin (PGE2), is most widely characterized in animal species, and exhibits versatile biological activities under physiological conditions. Prostacyclin (PGI2), affects many organ systems in human body and inhibits platelet activation and deposition of platelet on vascular surfaces. Prostaglandin D2 (PGD2) functions as a neuromodulator as well as trophic factor in the central nervous system and it is also involved in smooth musclar contraction or relaxation. ${ }^{1}$ Prostaglandin $F_{2 \alpha}$ $\left(\mathrm{PGF}_{2 \alpha}\right)$, functions in contraction and relaxation of smoother muscles and used for induction of abortions and also glaucoma. ${ }^{2}$ These prostaglandins are very promising moieties for the development of new therapeutic agents due to their strong physiological effects. Prostaglandins play key role in the generation of the inflammatory response and contribute to the development of the cardinal signs of acute inflammation. ${ }^{3}$

The initial treatment of glaucoma usually involves pilocarpine or epinephrine drugs and if treatment is not effective with these topically applied drugs, prostaglandins are employed for the treatment of glaucoma. Hence, latanoprost is the most widely used PG drug for effective treatment of glaucoma. ${ }^{4}$

\footnotetext{
*For correspondence
}

The synthetic prostaglandin (figure 1) misoprostol (1) doses are effective and high enough to reduce gastric acid secretion ${ }^{5}$ whereas tafluprost (2) is used as eye drops to control the progression of glaucoma and ocular hypertension. ${ }^{6}$ On the other hand, latanoprost (3) which relates structurally to $\mathrm{PGF}_{2 \alpha}$, is one of the prostaglandin analogues that continue to hold key positions in the treatment of glaucoma. The novel structure and biological profile of latanoprost has attracted the interest of synthetic community and reported various synthetic approaches for the synthesis of latanoprost. ${ }^{7}$ Recently, Martynow and co-workers have synthesized from (-)Corey lactone ${ }^{8}$ and Vidari and co-worker synthesized using Corey aldehyde. ${ }^{9}$

In view of the biological importance of latanoprost, the present study focused on the development of a new efficient, alternative route ${ }^{10}$ for the synthesis of latanoprost (3). This synthetic approach has been developed with high stereo selectivity and good yield using LiOH/MTBE and Swern oxidation, Witting Hornor reaction conditions as key steps. In the earlier method, the reduction of keto and alkene functional groups was achieved in two steps using expensive catalysts R-methyl oxazaborolidine in toluene/borane di methyl sulfide in THF and platinium oxide respectively ${ }^{11}$ whereas the present method illustrates a single step reaction using low cost $\mathrm{NiCl}_{2} / \mathrm{NaBH}_{4}$ catalyst in methanol. We also developed an efficient and enantio selective synthesis of optically active latanoprost with good yield employing flash purification method using acetonitrile/water mixture with an entirely different strategy. This strategy involves a concise divergent 


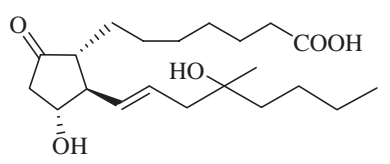

(1)

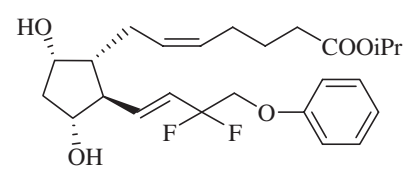

(2)

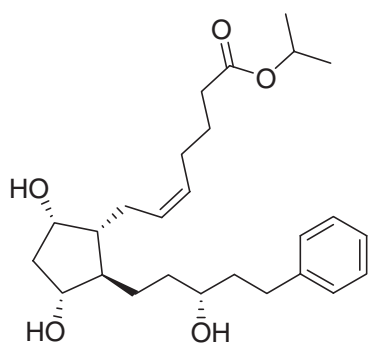

Latanoprost (3)

Figure 1. Structure of some of Prostaglandins.

synthesis of the target molecule from Corey lactone diol.

\section{Experimental}

\subsection{Materials and Methods}

All the reagents were purchased from Aldrich (SigmaAldrich, USA). Progress of the reactions was monitored by TLC, performed on silica gel glass plates containing 60 F-254. Column chromatography was performed with Merck 60-120 mesh silica gel. IR spectra were recorded on a Perkin-Elmer RX-1 FT-IR system. ${ }^{1} \mathrm{H}$ NMR spectra were recorded on a Bruker UXNMR/XWI-NMR$300 \mathrm{MHz}$ spectrometer. ${ }^{13} \mathrm{C}$ NMR $(75 \mathrm{MHz})$ spectra were recorded on Bruker Avance-300 MHz spectrometer. Chemical shifts $(\delta)$ are reported in parts per million (ppm) downfield from internal TMS standard. Peaks are labeled as singlet (s), doublet (d), triplet (t), quartet (q), and multiplet (m). ESI spectra were recorded on Micro mass, Quattro LC using ESI ${ }^{+}$software with a capillary voltage of $3.98 \mathrm{kV}$ and ESI mode positive ion trap detector. Optical rotations were measured with a Horiba-SEPA-300 digital polar meter.

\subsection{Synthesis}

2.2a Synthesis of 1-bromo-4-phenylbutan-2-one (5): To a stirred solution of 4-phenylbutan-2-one (4) (50 g, $1 \mathrm{mmol})$ in methanol $(350 \mathrm{~mL})$, bromine $(19 \mathrm{~mL}, 1.1$ mmol) was added at $0^{\circ} \mathrm{C}$ and the mixture was stirred at $15^{\circ} \mathrm{C}$ for $4 \mathrm{~h}$. After completion of reaction, the reaction mixture was diluted with water $(500 \mathrm{~mL})$ and extracted with dichloromethane $(2 \times 500 \mathrm{~mL})$. The collected organic layer was washed with brine solution and dried over anhydrous $\mathrm{Na}_{2} \mathrm{SO}_{4}$ and concentrated under reduced pressure. The residue was dissolved in pet ether and kept in refrigerator for $5 \mathrm{~h}$. The solid was filtered to afford compound 5 as a white solid $(72 \mathrm{~g}, 93.98 \%)$. ${ }^{1} \mathrm{H}$ NMR (300 MHz, $\left.\mathrm{CDCl}_{3}\right): \delta 2.9(\mathrm{q}, 4 \mathrm{H}), 3.8(\mathrm{~s}, 2 \mathrm{H}), 7.2$ (m, 3H), $7.3(\mathrm{~m}, 2 \mathrm{H}) .{ }^{13} \mathrm{C}$ NMR $\left(100 \mathrm{MHz}, \mathrm{CDCl}_{3}\right)$ : $\delta 29.87,34.24,41.38,126.34$ (2C), 128.28 (2C), 128.57 , $140.29,201.18$

2.2b Synthesis of dimethyl 2-oxo-4-phenylbutylphosphonate (6): To a degassed stirred solution of 5 (80 g, $1 \mathrm{mmol})$ in acetone $(480 \mathrm{~mL})$, was added sodium iodide (63 g, $1.2 \mathrm{mmol}$ ) and stirred at room temperature for $12 \mathrm{~h}$. After completion of the reaction, reaction mixture was filtered and washed with acetone $(200 \mathrm{~mL})$. Then the filtrate was evaporated in vacuo and obtained crude product was dissolved in dichloromethane (800 $\mathrm{mL})$, washed with water $(500 \mathrm{~mL})$ and brine solution $(500 \mathrm{~mL})$, dried over anhydrous $\mathrm{Na}_{2} \mathrm{SO}_{4}$. The collected organic solution was concentrated under reduced pressure to get iodo compound $(90 \mathrm{~g})$.

To a solution of iodo compound (90 g, $1 \mathrm{mmol})$ in acetonitrile $(450 \mathrm{~mL})$, tri methyl phosphate $(77.5 \mathrm{~mL}, 2$ mmol) was added at room temperature and stirred for 3 $\mathrm{h}$ at $65^{\circ} \mathrm{C}$. After completion of the reaction as indicated in TLC, excess of tri methyl phosphate was removed under high vacuum and obtained crude product purified by silica gel chromatography using ethyl acetate and hexane mixture (50:50) to afford compound $\mathbf{6}$ as a brown liquid (73 g, 86.73\%).

${ }^{1} \mathrm{H}$ NMR (300 MHz, $\left.\mathrm{CDCl}_{3}\right): \delta 2.9(\mathrm{q}, 4 \mathrm{H}), 3.0$ $(\mathrm{s}, 1 \mathrm{H}), 3.1(\mathrm{~s}, 1 \mathrm{H}), 3.75(\mathrm{~s}, 6 \mathrm{H}), 7.2(\mathrm{~m}, 3 \mathrm{H}), 7.3$ (m, 2H). ${ }^{13} \mathrm{C}$ NMR $\left(100 \mathrm{MHz}, \mathrm{CDCl}_{3}\right): \delta 29.35,40.81$, $42.08,45.45,52.92,52.98,126.11,128.32,128.41$, $140.47,200.80,200.86$.

2.2c Synthesis of $(3 a R, 4 S, 5 R, 6 a S)$-hexahydro-4,5-ditriethylsilane-4-(methyl)cyclopenta[b]furan-2-one (8): To a solution of compound 7 (50 g, $1 \mathrm{mmol})$ in pyridine $(500 \mathrm{~mL})$, triethyl silylchloride $(146 \mathrm{~mL}, 3 \mathrm{mmol})$ was added at room temperature and the mixture was stirred at $65^{\circ} \mathrm{C}$ for $4 \mathrm{~h}$. The solvent was removed under reduced pressure after completion of reaction, residue was dissolved in water $(400 \mathrm{~mL})$ and extracted with dichloro methane $(2 \times 500 \mathrm{~mL})$. The collected organic phases were washed with water followed by brine solution, dried over anhydrous $\mathrm{Na}_{2} \mathrm{SO}_{4}$ and concentrated under reduced pressure. The crude product was purified by silica gel chromatography using ethyl acetate and hexane (10:90) to furnish desired compound $\mathbf{8}$ as a colorless liquid (110 g, 94.55\%). ${ }^{1} \mathrm{H}$ NMR (300 MHz, $\left.\mathrm{CDCl}_{3}\right): \delta 0.6(\mathrm{~m}, 12 \mathrm{H}), 0.95(\mathrm{~J}=15.9 \mathrm{~Hz}, \mathrm{t}, 18 \mathrm{H}), 2$ 
$(\mathrm{m}, 2 \mathrm{H}), 2.25(\mathrm{~m}, 1 \mathrm{H}), 2.55(\mathrm{dd}, 1 \mathrm{H}), 2.75(\mathrm{~m}, 2 \mathrm{H})$, $3.55(\mathrm{~m}, 2 \mathrm{H}), 4.98(\mathrm{~m}, 1 \mathrm{H}), 4.15(\mathrm{~m}, 1 \mathrm{H}) .{ }^{13} \mathrm{C} \mathrm{NMR}$ (100 MHz, $\mathrm{CDCl}_{3}$ ): $\delta 4.22$ (3C), $4.63(3 \mathrm{C}), 5.73$ (2C), 6.50 (2C), 6.65 (2C), 35.57, 39.26, 41.07, 56.99, 62.41, $74.30,84.07,177.28$.

2.2d Synthesis of (3aR,4S,5R,6aS)-hexahydro-4,5-ditriethylsilane-4-(methyl)cyclopenta[b]furan-2-one (9): Oxalyl chloride (27 mL, $2.5 \mathrm{mmol})$ was discharged drop wise to a solution of dichloromethane $(500 \mathrm{~mL})$ and dimethyl sulphoxide $(28.5 \mathrm{~mL}, 3.5 \mathrm{mmol})$ at $-72^{\circ} \mathrm{C}$ for $40 \mathrm{~min}$ and stirred for $10 \mathrm{~min}$, then slowly added compound $\mathbf{8}(50 \mathrm{~g}, 1 \mathrm{mmol})$ to the reaction mixture and stirring continued for $4 \mathrm{~h}$ at the same temperature. The reaction mixture was quenched with triethyl amine $(100 \mathrm{~mL})$ at $-72^{\circ} \mathrm{C}$ and diluted with water $(300 \mathrm{~mL})$. Organic layer was extracted with dichloromethane (500 $\mathrm{mL}$ ), washed with brine solution and dried over anhydrous $\mathrm{Na}_{2} \mathrm{SO}_{4}$. After removal of solvent under reduced pressure the resulted crude aldehyde was used for the next step without further purification.

To a solution of compound 6 (32 g, $1 \mathrm{mmol})$ in methyl tertiary butyl ether $(500 \mathrm{~mL}) \mathrm{LiOH}^{\mathrm{H}} \mathrm{H}_{2} \mathrm{O}(4.9 \mathrm{~g}$, $0.95 \mathrm{mmol}$ ) was added at room temperature and reaction mixture was stirred for $1 \mathrm{~h}$ (solid precipitated). Then aldehyde compound was added to the reaction mixture at $5^{\circ} \mathrm{C}$ and stirred for another $10 \mathrm{~min}$. After that water $(18 \mathrm{~mL})$ was added and stirring continued for $45 \mathrm{~min}$. After completion of reaction, the reaction mixture was quenched with water $(500 \mathrm{~mL})$ and aqueous layers were extracted with ethyl acetate (500 $\mathrm{mL}$ ). The organic layer washed with brine solution and dried over anhydrous $\mathrm{Na}_{2} \mathrm{SO}_{4}$, evaporated under reduced pressure. The residue was purified by silica gel chromatography with ethyl acetate and hexane (30:70) solution to afford compound $\mathbf{9}$ as a yellow solid (27.5 g, 53.6\%). ${ }^{1} \mathrm{H}$ NMR $\left(300 \mathrm{MHz}, \mathrm{CDCl}_{3}\right): \delta 0.55$ (q, $6 \mathrm{H}), 0.9(\mathrm{~J}=10.8 \mathrm{~Hz}, \mathrm{t}, 9 \mathrm{H}), 2.0(\mathrm{~m}, 1 \mathrm{H}), 2.3(\mathrm{~m}$, $1 \mathrm{H}), 2.45(\mathrm{~J}=15 \mathrm{~Hz}, \mathrm{~d}, 1 \mathrm{H}), 2.55(\mathrm{~m}, 1 \mathrm{H}), 2.7-3.0$ $(\mathrm{m}, 6 \mathrm{H}), 4.0(\mathrm{~m}, 1 \mathrm{H}), 4.95(\mathrm{td}, 1 \mathrm{H}), 6.15(\mathrm{dd}, 1 \mathrm{H}), 6.1$ $(\mathrm{q}, 1 \mathrm{H}), 7.2(\mathrm{~J}=12.6 \mathrm{~Hz}, \mathrm{t}, 3 \mathrm{H}), 7.3(\mathrm{~J}=12.9 \mathrm{~Hz}, \mathrm{~d}, 2 \mathrm{H})$. ${ }^{13} \mathrm{C}$ NMR (100 MHz, $\mathrm{CDCl}_{3}$ ): $\delta 4.59$ (2C), 4.68, 6.61 (3C), 29.90, 31.70, 34.58, 41.72, 42.36, 56.78, 82.62, $83.02,125.81,127.89,128.16,128.29,128.45,131.06$, $145.35,140.91,176.17,198.55$.

2.2e Synthesis of (3aR,4R,5R,6aS)-hexahydro-5-hydroxy-4-((S,E)-3-triethylsilane-5-phenylpent-cyclopenta[b] furan-2-one (10): To a stirred solution of compound 9 $(25 \mathrm{~g}, 1 \mathrm{mmol})$ in methanol $(250 \mathrm{~mL}) \mathrm{NaBH}_{4}(4.56 \mathrm{~g}$, $2 \mathrm{mmol})$ and nickel chloride hexa hydrate (1.43 g, 0.1 mmol) was added at $0^{\circ} \mathrm{C}$ and the mixture was stirred for $3 \mathrm{~h}$ at the same temperature. After completion of the reaction, the reaction mixture was quenched with ammonium chloride solution at $0^{\circ} \mathrm{C}$. Organic solvent was removed under reduced pressure, aqueous layer was extracted with dichloromethane $(2 \times 250 \mathrm{~mL})$ and organic layer washed with brine solution, dried over anhydrous $\mathrm{Na}_{2} \mathrm{SO}_{4}$ and concentrated under reduced pressure to afford compound $\mathbf{1 0}$ as a colorless liquid (25 g, 99.04\%).

2.2f Synthesis of (3aR,4R,5R,6aS)-hexahydro-5-triethylsilane-4-((S,E)-3-triethylsilane-5-phenylpent-cyclopenta[b]furan-2-one (11): To a solution of compound 3 $(20 \mathrm{~g}, 1 \mathrm{mmol})$ in dichloromethane $(200 \mathrm{~mL})$ triethylamine $(40 \mathrm{~mL}, 6 \mathrm{mmol})$, triethylsilylchloride $(24.17$ $\mathrm{mL}, 3 \mathrm{mmol}$ ) was added drop wise at $5^{\circ} \mathrm{C}$ and the reaction mixture was stirred for $5 \mathrm{~h}$ at $10^{\circ} \mathrm{C}$. After completion of reaction, the reaction mixture was quenched with water $(140 \mathrm{~mL})$, then aqueous layer was extracted with dichloromethane $(250 \mathrm{~mL})$. The combined organic layer washed with brine solution, dried over anhydrous $\mathrm{Na}_{2} \mathrm{SO}_{4}$. The solvent was removed under reduced pressure and the obtained crude compound was purified by silica gel chromatography with mixture of ethyl acetate and hexane (10:90) to furnish the desired compound 11 as a colorless liquid (25 g, 98.23\%). ${ }^{1} \mathrm{H}$ NMR $\left(300 \mathrm{MHz}, \mathrm{CDCl}_{3}\right): \delta 0.6(\mathrm{q}, 12 \mathrm{H}), 0.95(\mathrm{~m}, 18 \mathrm{H})$, $1.35-1.55(\mathrm{~m}, 4 \mathrm{H}), 1.75(\mathrm{~m}, 3 \mathrm{H}), 2.0(\mathrm{dd}, 1 \mathrm{H}), 2.1$ $(\mathrm{m}, 1 \mathrm{H}), 2.48-2.83(\mathrm{~m}, 5 \mathrm{H}), 3.7(\mathrm{~m}, 1 \mathrm{H}), 3.94(\mathrm{~m}$, $1 \mathrm{H}), 4.95(\mathrm{~m}, 1 \mathrm{H}), 7.2(\mathrm{~m}, 3 \mathrm{H}), 7.3(\mathrm{~m}, 2 \mathrm{H})$.

$2.2 \mathrm{~g}$ Synthesis of $(3 a R, 4 R, 5 R, 6 a S)$-hexahydro-5-triethylsilane-4-((S,E)-3-triethylsilane-5-phenylpent-cyclopenta[b]furan-2-ol (12): To a solution of compound $4(27 \mathrm{~g}, 1 \mathrm{mmol})$ in THF (50 mL), DIBAL-H (176.89 $\mathrm{mL}, 3.5 \mathrm{mmol})$ was added dropwise at $-70^{\circ} \mathrm{C}$ and stirring was continued for $1 \mathrm{~h}$. After completion of reaction as indicated by TLC, the reaction mixture was quenched with methanol $(67.5 \mathrm{~mL})$ at below $-70^{\circ} \mathrm{C}$, then reaction temperature was raised to $5^{\circ} \mathrm{C}$ and water $(67.5 \mathrm{~mL})$, ethyl acetate $(270 \mathrm{~mL})$ were added and stirring continued for $30 \mathrm{~min}$ at room temperature (solid formed). The reaction mixture was filtered through a celite pad and washed thoroughly with ethyl acetate $(2 \times 150 \mathrm{~mL})$. Later, organic layer was washed with brine solution, dried over anhydrous $\mathrm{Na}_{2} \mathrm{SO}_{4}$ and concentrated under reduced pressure to give compound $\mathbf{1 2}$ as a colorless liquid ( $27 \mathrm{~g}, 99.6 \%)$.

2.2h Synthesis of (Z)-isopropyl7-((1R,2R,3R,5S)-3,5di-triethylsilane-2-((S,E)-3-triethylsilane-5-phenylpent- 
1-enyl)cyclopentyl)hept(3aR,4R,5R,6aS)-hexahydro-5triethylsilane-4-((S,E)-3-triethylsilane-5-phenylpent-cyclopenta[b]furan-2-one-5-enoate (13): To a solution of 4-carboxy butyl triphenyl phosphonium bromide (112 g, $5 \mathrm{mmol})$, potassium ter-butoxide $(45.31 \mathrm{~g}, 8$ $\mathrm{mmol})$ in THF $(270 \mathrm{~mL})$, compound $\mathbf{1 2}$ was added $(27 \mathrm{~g}, 1 \mathrm{mmol})$ in THF $(54 \mathrm{~mL})$ at $5^{\circ} \mathrm{C}$ and the reaction mixture was stirred for $6 \mathrm{~h}$. After completion of reaction, reaction mixture was poured into cold water $(270 \mathrm{~mL})$ and $\mathrm{pH}$ of the solution was adjusted to 2 using sodium bisulphate solution. Aqueous layer was extracted with ethyl acetate $(2 \times 270 \mathrm{~mL})$, the collected organic phase washed with brine solution, dried over anhydrous $\mathrm{Na}_{2} \mathrm{SO}_{4}$, concentrated under reduced pressure. The obtained crude acid compound $\mathbf{1 3}$ (40 g) was used for the next step without further purification.

To a solution of crude acid compound ( $40 \mathrm{~g}$ ) in acetone (1080 mL), 2-iodopropane (128.7 g, $15 \mathrm{mmol})$ and DBU (130.63 g, $17 \mathrm{mmol}$ ) was added at room temperature and the reaction mixture was stirred for $16 \mathrm{~h}$. After completion of reaction, the reaction mixture was filtered and washed with acetone. The organic solvent was removed completely under vacuum below $40^{\circ} \mathrm{C}$, the obtained residue dissolved in dichloromethane (400 $\mathrm{mL})$ and washed with citric acid solution $(400 \mathrm{~mL})$, sodium bicarbonate solution and brine solution and dried over anhydrous $\mathrm{Na}_{2} \mathrm{SO}_{4}$. The solvent removed under reduced pressure and obtained crude ester compound $13(55 \mathrm{~g})$ was subjected for the next step without further purification.

The solution of crude ester compound (55 g) in dichloromethane $(800 \mathrm{~mL})$, triethylamine $(70.8 \mathrm{~mL}$, $10 \mathrm{mmol}$ ) was added and triethylsilylchloride $(51 \mathrm{~mL}$, $6 \mathrm{mmol}$ ) was added drop wise at $5^{\circ} \mathrm{C}$ and the reaction mixture was stirred at $10^{\circ} \mathrm{C}$ for $6 \mathrm{~h}$. After completion of the reaction, water was added; aqueous layers were extracted with dichloromethane $(2 \times 400 \mathrm{~mL})$. The combined organic layer washed with brine solution, dried over anhydrous $\mathrm{Na}_{2} \mathrm{SO}_{4}$, evaporated under vacuum. The residue was purified by silicagel column chromatography with ethyl acetate and hexane (10:90) mixture to afford compound $\mathbf{1 3}$ as a colorless liquid (33 g, 84.33\%). ${ }^{1} \mathrm{H}$ NMR $\left(300 \mathrm{MHz}, \mathrm{CDCl}_{3}\right): \delta 0.6$ $(\mathrm{m}, 18 \mathrm{H}), 0.9(\mathrm{~m}, 27 \mathrm{H}), 1.25(\mathrm{~J}=6.3 \mathrm{~Hz}, \mathrm{~d}, 6 \mathrm{H}), 1.4$ $(\mathrm{m}, 2 \mathrm{H}), 1.5(\mathrm{q}, 2 \mathrm{H}), 1.65-1.8(\mathrm{~m}, 6 \mathrm{H}), 2.0-2.3$ $(\mathrm{m}, 8 \mathrm{H}), 2.65(\mathrm{~m}, 2 \mathrm{H}), 3.7(\mathrm{~m}, 2 \mathrm{H}), 4.1(\mathrm{q}, 1 \mathrm{H}), 5.0$ $(\mathrm{m}, 1 \mathrm{H}), 5.4(\mathrm{~m}, 2 \mathrm{H}) 7.2(\mathrm{~m}, 3 \mathrm{H}), 7.3(\mathrm{~m}, 2 \mathrm{H})$.

$2.2 \mathrm{i}$ Synthesis of (Z)-isopropyl7-((1R,2R,3R,5S)-3,5dihydroxy-2-((R)-3-hydroxy-5- phenylpentyl)cyclopentyl $)$ hept-5-enoate(14): To a solution of compound 13 (30 $\mathrm{g}, 1 \mathrm{mmol})$ in THF $(300 \mathrm{~mL})$ was added, acetic acid
$(150 \mathrm{~mL})$ and water $(150 \mathrm{~mL})$ at room temperature and the reaction mixture was stirred for $8 \mathrm{~h}$. After completion of the reaction, the reaction mixture was diluted with water $(150 \mathrm{~mL})$. Aqueous solution was extracted with ethyl acetate $(2 \times 200 \mathrm{~mL})$, the organic phase was washed with saturated solution of $\mathrm{NaHCO}_{3}$, brine solution and dried over anhydrous $\mathrm{Na}_{2} \mathrm{SO}_{4}$, evaporated under vacuum. The residue was purified by silica gel column chromatography using dichloromethane and acetone (70:30) to afford compound $\mathbf{1 4}$ as a colorless liquid $(15 \mathrm{~g}, 89.65 \%)$.

2.2j Synthesis of (Z)-isopropyl7-((1R,2R,3R,5S)-3,5-dihydroxy-2-((R)-3-hydroxy-5- phenylpentyl)cyclopentyl) hept-5-enoate $(3)$ : The compound $14(20 \mathrm{~g})$ was purified by flash purification method using silica $(40 \mathrm{~mm})$ chromatography with acetonitrile and water mixture to afford pure compound $\mathbf{3}$ as a colorless liquid (12g). ${ }^{1} \mathrm{H}$ NMR $\left(300 \mathrm{MHz}, \mathrm{CDCl}_{3}\right): \delta 1.25(\mathrm{~J}=6.3 \mathrm{~Hz}, \mathrm{~d}$, $6 \mathrm{H}), 1.45(\mathrm{~m}, 2 \mathrm{H}), 1.5(\mathrm{q}, 2 \mathrm{H}), 1.65-1.8(\mathrm{~m}, 6 \mathrm{H}), 1.9$ $(\mathrm{J}=6 \mathrm{~Hz}, \mathrm{t}, 2 \mathrm{H}), 2.1-2.4(\mathrm{~m}, 8 \mathrm{H}), 2.75(\mathrm{~m}, 3 \mathrm{H}), 3.65$ $(\mathrm{m}, 1 \mathrm{H}), 3.95(\mathrm{~J}=2.4 \mathrm{~Hz}, \mathrm{~d}, 1 \mathrm{H}), 4.18(\mathrm{q}, 1 \mathrm{H}), 5.0$ $(\mathrm{m}, 1 \mathrm{H}), 5.45(\mathrm{~m}, 2 \mathrm{H}) 7.2(\mathrm{~J}=16.2 \mathrm{~Hz}, \mathrm{t}, 3 \mathrm{H}), 7.3(\mathrm{~J}=7.8$ $\mathrm{Hz}, \mathrm{d}, 2 \mathrm{H}) .{ }^{13} \mathrm{C}$ NMR $\left(125 \mathrm{MHz}, \mathrm{CDCl}_{3}\right): \delta 21.76(2 \mathrm{C})$, 24.88, 26.56, 29.53, 32.06, 34.01, 35.72, 38.97, 42.46, $51.75,52.67,67.60,71.23,74.48,78.62,125.73,128.33$ (4C), 129.34, 129.44, 142.09, 173.46. IR (Neat, $\mathrm{cm}^{-1}$ ): $\gamma_{\max } 1108,1728,2860,2932,2978,3394$. Mass (ESI) $\mathrm{m} / \mathrm{z}: 433.2(\mathrm{M}+1) ; \mathrm{m} / \mathrm{z}$ calcd for $\mathrm{C}_{26} \mathrm{H}_{40} \mathrm{O}_{5}[\mathrm{M}+1]$ 433.2; found: 433.17 .

\section{Results and Discussion}

The retro synthetic approach for the synthesis of latanoprost (3) is outlined in scheme 1. The latanoprost can be prepared from intermediate 12. Intermediate $\mathbf{1 2}$

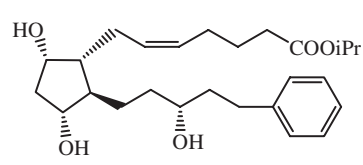

Latanoprost (3)
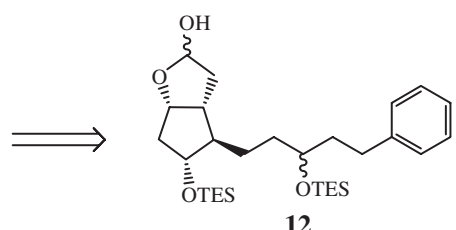

12

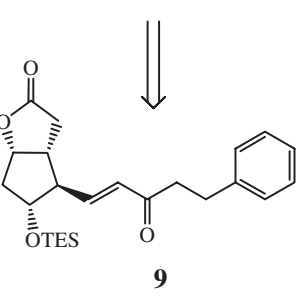

Corey lactone diol (7)

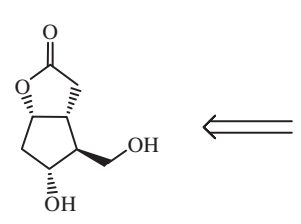

Corey lactone diol (7)

Scheme 1. Retro synthetic approach for Latanoprost (3). 
can be synthesized from 9 which can be prepared from Corey lactone diol (7).

In accordance with the synthetic plan, our synthesis began with the bromination reaction of 4-phenylbutan2one 4 to obtain 1-bromo-4-phenylbutan-2-one 5. The compound $\mathbf{5}$ was transformed to iodo intermediate by treating with $\mathrm{NaI}$ in acetone at $30^{\circ} \mathrm{C}$ for $12 \mathrm{~h}$. This intermediate (without isolation) was further treated with tri methyl phosphate to support the compound $\mathbf{6}$ in good yield as shown in scheme 2 .
The Corey lactone diol (7) utilized for the synthesis of latanoprost (3) was purchased from Hwasun biotechnology, China (CAS NO-32233-40-2). The diol 7 was protected by triethylsilylchloride in presence of pyridine at $65^{\circ} \mathrm{C}$ for $4 \mathrm{~h}$, resulted compound 8 . Then it was subjected to Swern's oxidation to afford the mono protected aldehyde, which afforded compound $\mathbf{9}$ in good yield on treatment with compound $\mathbf{6}$ under Wittig reaction conditions. The allylic double bond of compound 9 was reduced by stirring with nickel chloride

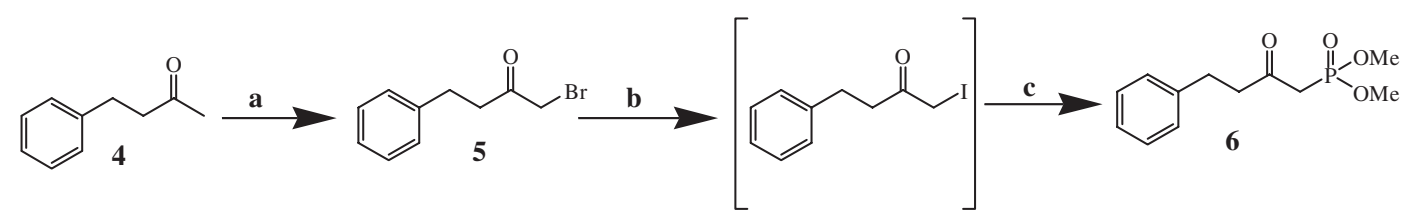

Scheme 2. Reagents and Conditions: (a) $\mathrm{Br}_{2}$, methanol, $0^{\circ} \mathrm{C}, 4 \mathrm{~h}$; (b) NaI, acetone, $27^{\circ} \mathrm{C}, 12 \mathrm{~h}$; (c) $\left(\mathrm{CH}_{3}\right)_{3} \mathrm{PO}_{4}$, acetonitrile, $65^{\circ} \mathrm{C}, 3 \mathrm{~h}$.

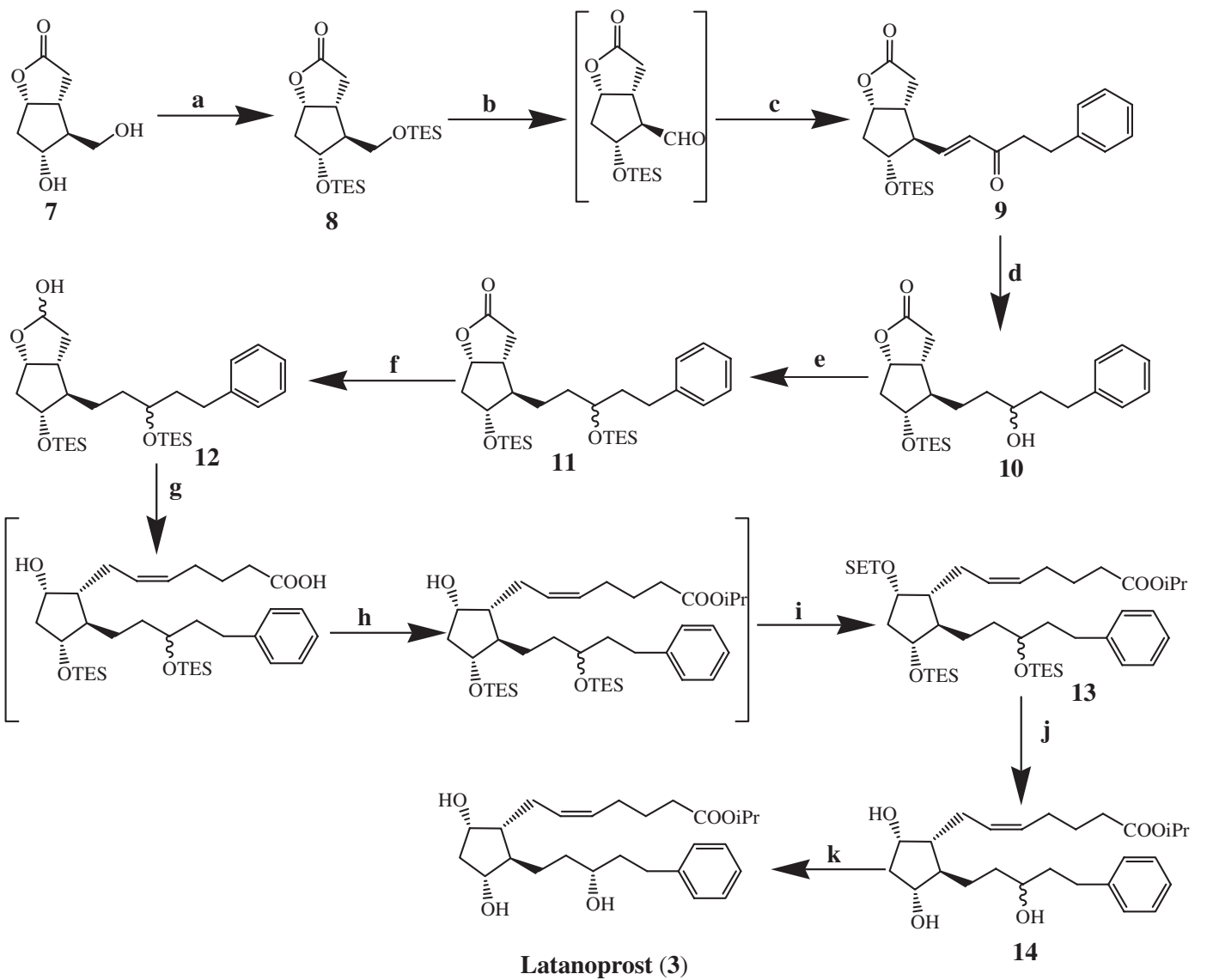

Scheme 3. Reagents and Conditions: (a) Triethyl silylchloride, pyridine, $65^{\circ} \mathrm{C}, 4 \mathrm{~h}$; (b) $(\mathrm{COCl})_{2}$, DMSO, $\mathrm{Et}_{3} \mathrm{~N}, \mathrm{CH}_{2} \mathrm{Cl}_{2},-72^{\circ} \mathrm{C}, 4 \mathrm{~h}$; (c) Compound 6, methyl tertiary butyl ether, $\mathrm{LiOH} . \mathrm{H}_{2} \mathrm{O}, 5^{\circ} \mathrm{C}$, 45 min; (d) $\mathrm{NiCl}_{2} \cdot 6 \mathrm{H}_{2} \mathrm{O}$, methanol, $\mathrm{NaBH}_{4}, 0^{\circ} \mathrm{C}, 3 \mathrm{~h}$; (e) Triethyl silylchloride, TEA, $\mathrm{CH}_{2} \mathrm{Cl}_{2}, 5^{\circ} \mathrm{C}$, $5 \mathrm{~h}$; (f) DIBAL-H, dry THF, $-70^{\circ} \mathrm{C}, 60 \mathrm{~min}$; (g) 4-Carboxy butyl triphenyl phosphonium bromide, t-BuOK, THF, $5^{\circ} \mathrm{C}, 6 \mathrm{~h}$; (h) 2-Iodopropane, DBU, dry acetone, $30^{\circ} \mathrm{C}, 16 \mathrm{~h}$; (i) Triethyl silylchloride, TEA, $\mathrm{CH}_{2} \mathrm{Cl}_{2}, 5^{\circ} \mathrm{C}, 6 \mathrm{~h}$; (j) aq AcOH, THF, $30^{\circ} \mathrm{C}, 8 \mathrm{~h}$; (k) flash purification. 
hexahydrate, sodium borohydride in methanol for $3 \mathrm{~h}$ at $0^{\circ} \mathrm{C}$ which resulted in hydroxyl derivative compound 10. The hydroxyl group present in compound $\mathbf{1 0}$ was protected by triethylsilylchloride with triethylamine in dichloromethane at $5^{\circ} \mathrm{C}$ for $5 \mathrm{~h}$, to obtain compound $\mathbf{1 1}$ in good yield.

The lactone ring of compound $\mathbf{1 1}$ was reduced with DIBAL-H in THF at $-70^{\circ} \mathrm{C}$ for $1 \mathrm{~h}$ to give compound 12. The lactone ring of compound $\mathbf{1 2}$ was cleaved by reacting with 4-carboxy butyl triphenylphosphonium bromide and potassium tert-butoxide in THF at $5^{\circ} \mathrm{C}$ for $6 \mathrm{~h}$ under Wittig conditions. The resulted Wittig compound without further purification was subjected for esterification reaction by treating with DBU and 2Iodopropane in dry acetone at $30^{\circ} \mathrm{C}$ for $16 \mathrm{~h}$ to have isopropyl ester compound. This crude compound was treated with triethylsilylchloride and triethylamine in dichloromethane at $5^{\circ} \mathrm{C}$ for $6 \mathrm{~h}$ to afford TES protected compound 13 with quantitative yield.

Finally, deprotection of compound $\mathbf{1 3}$ with aqueous acetic acid and THF solvent at $30^{\circ} \mathrm{C}$ for $8 \mathrm{~h}$ was done to obtain target compound $\mathbf{1 4}$ with good yield and was separated by flash purification to get target molecule enantiopure latanoprost 3 . The physical and spectroscopic data of $\mathbf{3}$ were in congruence with reported data in the literature. ${ }^{8}$ The present methodology provides an enhanced stereo selectivity and efficient synthetic approach for the synthesis of compound $\mathbf{3}$ with good yield as shown in scheme 3 .

\section{Conclusions}

In the present study, an attempt has been made to develop a simple, convenient and convergent approach for the synthesis of latanoprost $\mathbf{3}$ using Corey lactone diol under Swern oxidation, allylic reduction and Wittig reaction conditions. This new synthetic protocol provides good stereo selectivity and an efficient alternative synthetic route for the synthesis of compound $\mathbf{3}$ in good yield.

\section{Supplementary Information}

The supplementary information pertaining to characterization of the synthesized compounds using ${ }^{1} \mathrm{H}$ NMR spectra (figures S1-S7), ${ }^{13} \mathrm{C}$ NMR spectra (figures S8S12), IR spectra (figures S13) HPLC chromatogram (figure S14), Mass spectra (figure S15) and SOR spectrum data (table S1) are available at www.ias.ac.in/ chemsci.

\section{Acknowledgements}

One of the authors $\mathrm{KV}$ is grateful to the Aspen Bio Pharma Labs Pvt. Ltd for providing research opportunity to carry out his research program.

\section{References}

1. Das S, Chandrasekhar S, Yadav J S and Grée R 2007 Chem. Rev. 1073286

2. Bito L Z, Camras C B, Gum G G, Resul B, Bito L Z and Stjernschantz J 1989 In The ocular hypotensive effects and side effects of prostaglandins on the eyes of experimental animals. The Ocular Effects of Prostaglandins and Other Eicosanoids (New York: Alan R Liss) p. 349

3. (a) Feng Z, Hellberg M R, Sharif N A, McLaughlin M A, Williams G W, Scott D and Wallace Tony 2009 Bioorgan. Med. Chem. 17 576; (b) Ricciotti E and FitzGerald G A 2011 Arterioscler. Thromb. Vasc. Biol. 31986

4. Resul B, Stjernschantz J, No K, Liljebris C, Selen G, Astin M, Karlsson M and Bito L Z 1993 J. Med. Chem. 36243

5. Lee A S-Y and Wu C-W 1999 Tetrahedron 5512531

6. Fukano Y and Kawazu K 2009 Drug Metab. Dispos. 37 1622

7. (a) Corey E J and Christopher J H 1997 Tetrahedron Lett. 38 7511; (b) Corey E J 1991 Angew Chem. Int. ed. 30 455; (c) Corey E J, Weinshenker N M, Schaaf T K and Huber W 1969 J. Am. Chem. Soc. 91 5675; (d) Corey E J, Schaaf T K, Huber W, Koelliker U and Weinshenker N M 1970 J. Am. Chem. Soc. 92 397; (e) Wang X-G, Wang A-E, Hao Yi, Ruan Y-P and Huang P-Q 2013 J. Org. Chem. 789488

8. Jacek G M, Julita J W, Wiesław S, Osman A, Andrzej K, Krzysztof W N, Jerzy W, Oliwia Z-S and Piotr G B 2007 Eur. J. Org. Chem. 689

9. Giuseppe Z, Alessandro D A, Porta A, Lazzaro F, Steven P N and Giovanni V 2010 Tetrahedron 667472

10. Kambe T, Maruyama T, Nakai Y, Yoshide H, Oida H and Maruyama T 2012 Bioorgan. Med. Chem. 202235

11. (a) Alonso F, Candela P, Gomez C and Yus M 2003 Adv. Synth. Catal. 345 275; (b) Jitender M, Khurana E, Dawra K and Majumdar S 2009 Monatsh Chem. 140 69 